\title{
IbM Pembuatan Tenun Bukan Mesin (Tbm) Bermotif Untuk Bahan Baku Kerajinan Tangan di Desa Waung Kecamatan Boyolangu Kabupaten Tulungagung
}

\author{
Wenni Wahyuandari dan Nurani \\ Universitas Tulungagung \\ wahyuandari@gmail.com, nuraniaziz@gmail.com
}

\begin{abstract}
The people of Waung have been blessed with a non -machinery waving skill (Tenun Bukan Mesin/ TBM) which learned from their ancestors. The product is not only seen as a beautiful art but it has also an added economic value. It can contribute to the increase of the family income if the product can meet what the market really needs and well managed. The traditional waving has not developed fast in the coming of modern era because of its limited use, competiveness and conventional marketing. Only the women usually buy it used as a corset. These facts indicate that they have got the productive and the managerial problems. They rarely get any training to produce waving with a new trend and to expand their market using IT. To solve problems there should be productive and managerial training programs to protect them so can be preserved as a meaningful Indonesian heritage and even will elevate people's income as well. The training aims to equip the people with the skills how to make motif waving as a raw material to produce the various kinds of accessories/souvenirs (wallet, tissue box, wall decoration, pillowcase, bag, pencil case). In the managerial domain, people are importantly enriched with the skills to make financial report and make on-line marketing. The method uses social approach. This means that group of waving community, housewives, unemployed youth, stakeholders get involved during the implementation of the program from planning evaluation.
\end{abstract}

Keyword : Weaving Not Machine Motif; Crafts; Waung Boyolangu

\begin{abstract}
Abstrak
Desa Waung Kecamatan Boyolangu Kabupaten Tulungagung memiliki potensi membuat tenun bukan mesin (TBM). Potensi ini adalah berkah karena tenun tidak hanya memiliki nilai ekonomi tetapi bernilai seni. Permasalahan yang dihadapi kedua mitra terkait dengan Sumber Daya Manusia, produksi dan manajemen. Mereka tidak memiliki pengetahuan dan ketrampilan bagaimana cara membuat tenun bermotif agar ketrampilan menenun tanpa mesin bisa berlanjut menjadi warisan budaya, memiliki nilai seni yang bernilai jual tinggi dan memiliki beraneka ragam manfaat sehingga menjadi sumber tambahan penghasilan masyarakat. Sedangkan masalah aspek manajemen bagaimana cara memasarkan hasil Kerajinan Tenun Bermotif sehingga jangkauan pemasaran lebih luas dengan memaksimalkan IT. Solusi dari permasalahan ini, pertama dengan memproduksi tenun bukan mesin (TBM) bermotif sebagai bahan baku kerajinan tangan tenun seperti dompet, tempat tisu, hiasan dinding, sarung bantal, tas, kotak pensil. Kedua, peningkatan kualitas SDM melalui berbagai kegiatan pelatihan terkait dengan manajemen SDM, produksi, keuangan dan pemasaran berbasis online. Metode pelaksanaan melibatkan kelompok pengarajin tenun bukan mesin, ibu-ibu rumah tangga, remaja belum bekerja, pemangku kepentingan, masyarakat terlibat dalam berbagai tahapan kegiatan mulai dari perencanaan sampai evaluasi dalam beberapa tahapan (sosialisasi, perencanaan, pelaksanaan dan evaluasi).
\end{abstract}

Kata Kunci : Tenun Bukan Mesin Bermotif; Kerajinan Tangan; Desa Waung Boyolangu 


\section{A. PENDAHULUAN}

Kerajinan membuat tenun bukan mesin (TBM) dapat ditemukan di beberapa wilayah di Indonesia, salah satunya di, Desa Waung, Kecamatan Boyolangu, Kabupaten Tulungagung. ketrampilan menenun traditional diwariskan sejak jaman nenek moyang Kerajinan tersebut memiliki tidak hanya memiliki nilai budaya seni tetapi juga nilai ekonomi dan minim polusi sehingga perlu dilestarikandan. Sebelum era teknologi tekstil, hasil tenun pada umumnya dipakai sebagai bahan baku stagen/ pengikat (bahasa Jawa "centhing") dipakai oleh ibu-ibu yang baru melahirkan agar perutnya tidak buncit, penari/sinden (pelantun gending jawa pada pentas wayang) untuk mengikat kain panjang. Seiring dengan perkembangan teknologi di bidang tektil kebutuhan akan stagen menurun karena masyarakat lebih memilih menggunakan korset yang dianggap lebih praktis daripada stage. Merujuk pada realitas ini perlu dilakukan upaya-upaya untuk melakukan pembinaan agar tetap eksis dan menjadi sumber pendapatan keluarga dengan cara melakukan inovasi produk dan meningkatkan utiliti produk sesuai dengan kebutuhanh pasar. Hasil tenun tidak hanya dibuat untuk stagen tetapi dibuat untuk beragam aksesories (pernak pernik yang mempercantik rumah dan diperuntukan sovenir hajatan seperti tempat tisu, dompet, hiasan dinding, tas unik) dipadupadankan/dikombinasikan dengan misalnya batik. Apabila inovasi-inovasi / kreasi tenun dilakukan diharapkan dapat memberi nilai seni dan juga ekonomi yang lebih baik.

Masalah yang dihadapi Mitra I dan II meliputi aspek produksi dan manajemen. Permasalahan aspek produksi adalah bagaimana cara membuat tenun bermotif agar supaya ketrampilan menenun tanpa mesin bisa dilestarikan sebagai warisan budaya dan sekaligus memiliki nilai seni dan barang seni bernilai jual guna meningkatkan penghasilan masyarakat desa Waung. Sedangkan masalah aspek managemen adalah bagaimana cara membuat buku kas dan pelaporan keuangan serta memasarkan hasil Kerajinan Tenun Bermotif di Desa Waung dengan memanfaatkan IT.

Dari hasil pengamatan lapang, data sekunder (data kependudukan), dan juga wawancara dengan mitra yang dilakukan selama studi pendahuluan ditemukan masih terdapat $35 \%$ penduduk berada pada level golongan ekonomi menengah ke bawah. Omzet yang tidak menentu setiap bulan karena penjualan sangat tergantung pada permintaan pasar, mengingat bahwa pengrajin hanya memproduksi tenun sebagai bahan stagen. Seiring dengan perkembangan teknologi fungsi stagen digantikan dengan korset, semakin tidak kondusif aspek produksi dan manajemennya. Merujuk pada situasi tersebut, program prioritas IbM difokuskan pada upaya untuk menumbuhkan kembali semangat masyarakat (mitra) yang memiliki kemampuan menenun dengan memperbaiki aspek produksi dan manajemen dengan memberikan pelatihan. Mereka yang memiliki kemampuan tenun di beri pelatihan membuat tenun bermotif, membuat beragam aksesories dengan menggunakan bahan baku tenun yang diproduksi. Selain pelatihan aspek produksi, aspek pemasaran pun menjadi perhatian. Bagaimana hasil produksi itu dapat dipasarkan tidak hanya di pedagang kain di pasar dan took tetapi dapat diperluas jangkauannya dengan menggunakan koperasi dan media sosial (online). 


\section{B. PELAKSANAAN DAN METODE}

Untuk merealisasi pendekatan tersebut, langkah yang ditempuh dalam memecahkan permasalahan adalah sebagai berikut: (1) Sosialisasi rencana kegiatan $\Rightarrow$ diskusi dengan mitra untuk inventarisasi permasalahan-permasalahan yang ada serta mencari pemecahan masalah; (2) Merencanakan, menyusun, dan melaksanakan kegiatan terkait dengan masalah-masalah produksi dan managemen yang dihadapi dengan mengadakan pelatihan-pelatihan memproduksi tenun bermotif, membuat aksesories berbahan baku tenun, melatih managemen produksi, keuangan dan pemasaran untuk mengembangkan produk yang memiliki nilai jual, mampu berkompetisi dalam harga dan kualitas sehingga membantu peningkatan pendapatan keluarga; (3) Mengevaluasi pelaksanaan kegiatan untuk memperoleh masukan dalam penyempurnaan program selanjutnya.

Terkait dengan masalah yang dihadapi mitra, metode pelaksanaan kegiatan ini melakukan pendekatan kemasyarakatan dengan cara melibatkan kelompok pengarajin tenun bukan mesin dan ibu-ibu rumah tangga, remaja belum bekerja, pemangku kepentingan, masyarakat terlibat dalam berbagai tahapan kegiatan mulai dari perencanaan sampai evaluasi.

Partisipasi masyarakat sangat diperlukan dalam bentuk dukungan aktif dari mitra, partisipasi mitra dapat dilakukan dengan prosedur kerja : berdiskusi mengenai masalah yang di hadapai dan solusi (aspek produksi dan manajemen) yang akan dilakukan dalam meningkatkan mutu dan pengembangan produk berbahan baku tenun bukan mesin serta inovasi manajemen.

Sedangkan evaluasi program nantinya dilakukan dengan menganalisis hasil kegiatan tersebut dengan cara mengidentifikasi capaian, kendala, faktor-faktor pendukung, dampak kegiatan. Sedangkan untuk menjaga keberlanjutan program akan dilakukan monitoring secara periodik dan mlibatkan relawan serta bekerjasma dengan berbagai pihak terkait dengan mitra.

\section{HASIL DAN LUARAN YANG DICAPAI}

Pada bagian ini, pelaksana pengabdian masyarakat mendiskripsikan kegiatan program pengabdian kepada masyarakat yang sudah dilakukan. Kegiatan pengabdian kepada masyarakat yang telah dilaksanakan bertujuan untuk membantu masyarakat dan pemerintah menjaga kelestarian dan keberlanjutan keberadan kerajinan tenun bukan mesin yang menjadi warisan budaya yang bernilai tinggi bangsa Indonesia khususnya yang berada di Dusun Talapan Desa Waung Kecamatan Boyolangu, kabupaten tulungagung Propinsi Jawa Timur. Kegiatan pembinan pengrajin tenun sangat diperlukan karena manakala tidak dilakukan tidak mustahil warisan budaya di bidang penenunan ini punah karena kehadiran industri tekstil yang sangat kopetitif dan penggunaan IT dalam pemasaran produk.

Dengan pembinaan diharapkan para pengrajin tenun bukan mesin (TBM) dapat meningkatkan nilai seni dan nilai jual serta lebih dikenal oleh masyarakat luas melalui pemasaran di media social. Dengan melakukan inovasi produksi dan memanfaatkan tehnologi dalam memperkenalkan produk diharapkan masyarakat di luar Tulungagung bisa mengenal dan tertarik untuk membeli. Peningkatan permintaan produksi juga akan memperbaiki pendapatan keluarga serta membuka lapangan kerja bagi ibu-ibu rumah tangga. 
Pelaksanaan kegiatan IbM ini melibatkan masyarakat dan aparat desa dengan cara melakukan musyawarah membuat komitmen. Berikut ini adalah kegiatan yang bisa dilaporkan :

\section{Pengadaan Peralatan Produksi}

Tujuan Peningkatan : kualitas dan kuantitas produksi

Metode Pelaksanaan : Swakelola

Luaran

: ATBM yang di modifikasi, Mesin Jahit, Mesin Obras Spesifikasi

a) ATBM : Bahan rangka jati ukuran $160 \times 120 \times 160$ cm untuk lebar kain $\quad 105-120 \mathrm{~cm}$, Sisir (ukuran 80 ), Tiker Atau Plikes, Gun, Rentengan atau Ril dan Sekoci berfungsi untuk menenu8n benang menjadi kain.

b) Mesin Jahit : JUKI DDL-5550N-7 berfungsi menjahit sambungan antara bahan yang satu dengan bahan yang lain atau untuk menempelkan atribut pada bahan utama. Dapat membuat pola jahitan yang diinginkan secara otomatis / terprogram, sehingga lebih menghemat SDM \& waktu. Mesin ini dapat di gunakan untuk menjahit berbagai jenis bahan seperti bahan catton, viscose, jersey, lotto, paragon, dll.

c) Mesin Obras : Mesin obras 3 benang Singer 81A1 dengan spesifikasi panjang jahitan bisa diatur 2,5$3,5 \mathrm{~mm}$, ketinggian sepatu: $3 \mathrm{~mm}$, speed $8000 \mathrm{rpm}$ dan berat $25 \mathrm{~kg}$ cocok untuk rumah maupun usaha jahitan, butik, atau usaha garment skala kecil lainnya. Mesin ini bisa dirubah untuk fungsi jahitan tepi (neci).

Gambar 1. Alat Tenun Bukan Mesin (ATBM)
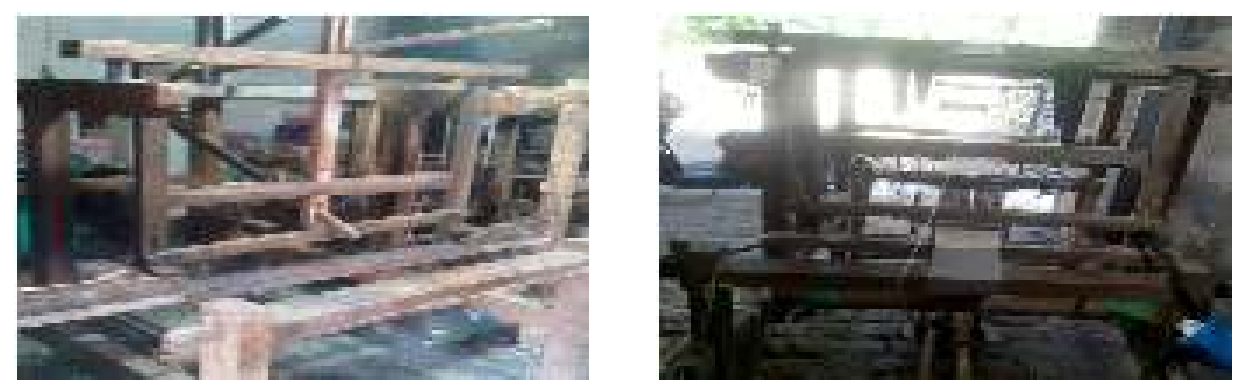
Gambar 2. Peralatan Penunjang Produksi Tenun
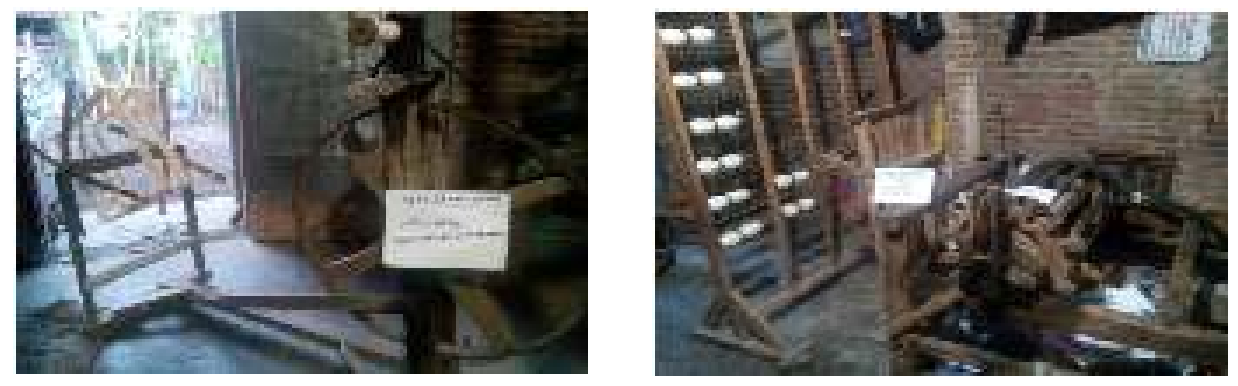

Gambar 3. Mesin Jahit
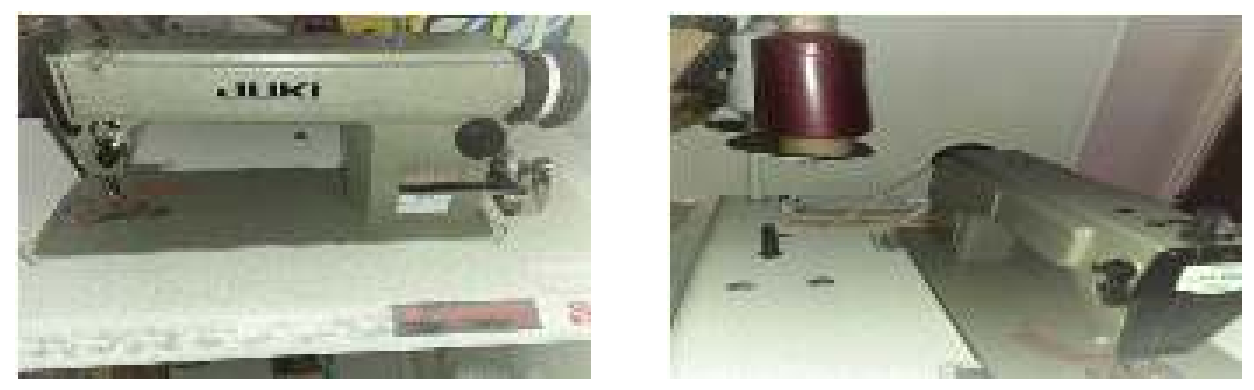

Gambar 4. Mesin Obras
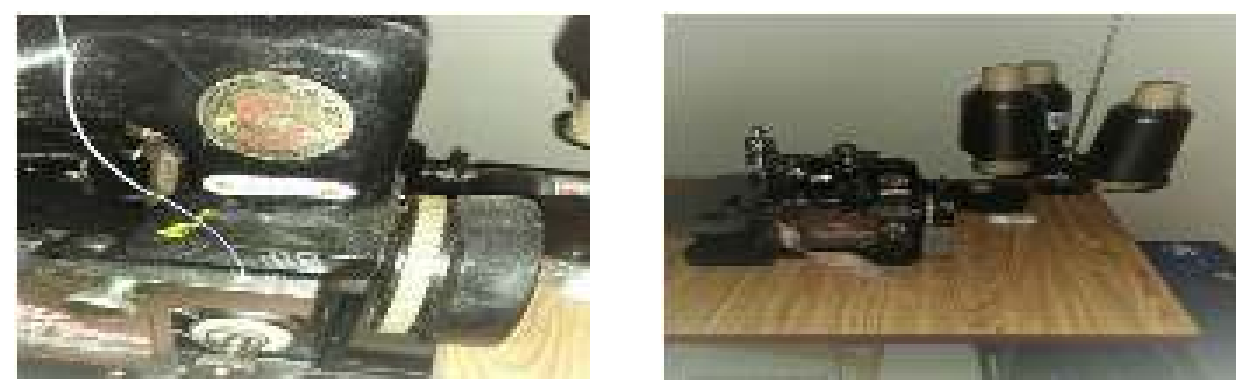

Pelatihan Produksi Tenun

Tujuan Pelatihan

Metode Pelaksanaan

Peserta

Instructor

Waktu Pelaksanaan
: Meningkatkan kualitas dan kuantitas melalui kreatifitas produksi (tenun bermotif)

: Praktek

: Pengrajin tenun bukan mesin di Dusun Talapan Desa Waung, Boyolangu Tulungagung

: 1. Bpk. Munawar dari kerajinan Tenun Ikat "Medali Emas" Jl. Haji Agus Salim 103 Bandar Lor Kediri

2. Imam Sukemi, pengrajin tenun Dusun Talapan Desa Waung Kecamatan Boyolangu Kab. Tuulungagung

3. Siti Rofiah, SAP

4. Dra. Zulfa

: 09 Juli 2017 
Tempat Pelaksanan

Luaran
: Dusun Talapan RT. 01 RW 06, Desa Waung Kecamatan Boyolangu, Tulungagung

: Tenun motif dan berbagai macam aksesories

Prosedur pelaksanaan kegiatan pelatihan pembuatan tenun bukan mesin bermotif:

a) Mempersiapkan modul panduan proses pembuatan tenun bukan mesin dan pembuatan aksesories

b) Mengkopi dan membagikan modul pelatihan sebanyak peserta pelatihan

c) Instruktur menjelaskan proses produksi dan memberi contoh pelaksanaanya

d) Instruktur menjelaskan bagaimana membuat bermacam-macam aksesories

e) Peserta pelatihan mempraktek teori yang diperoleh

Proses produksi tenun bermotif secara singkat dijelaskan sebagai berikut :

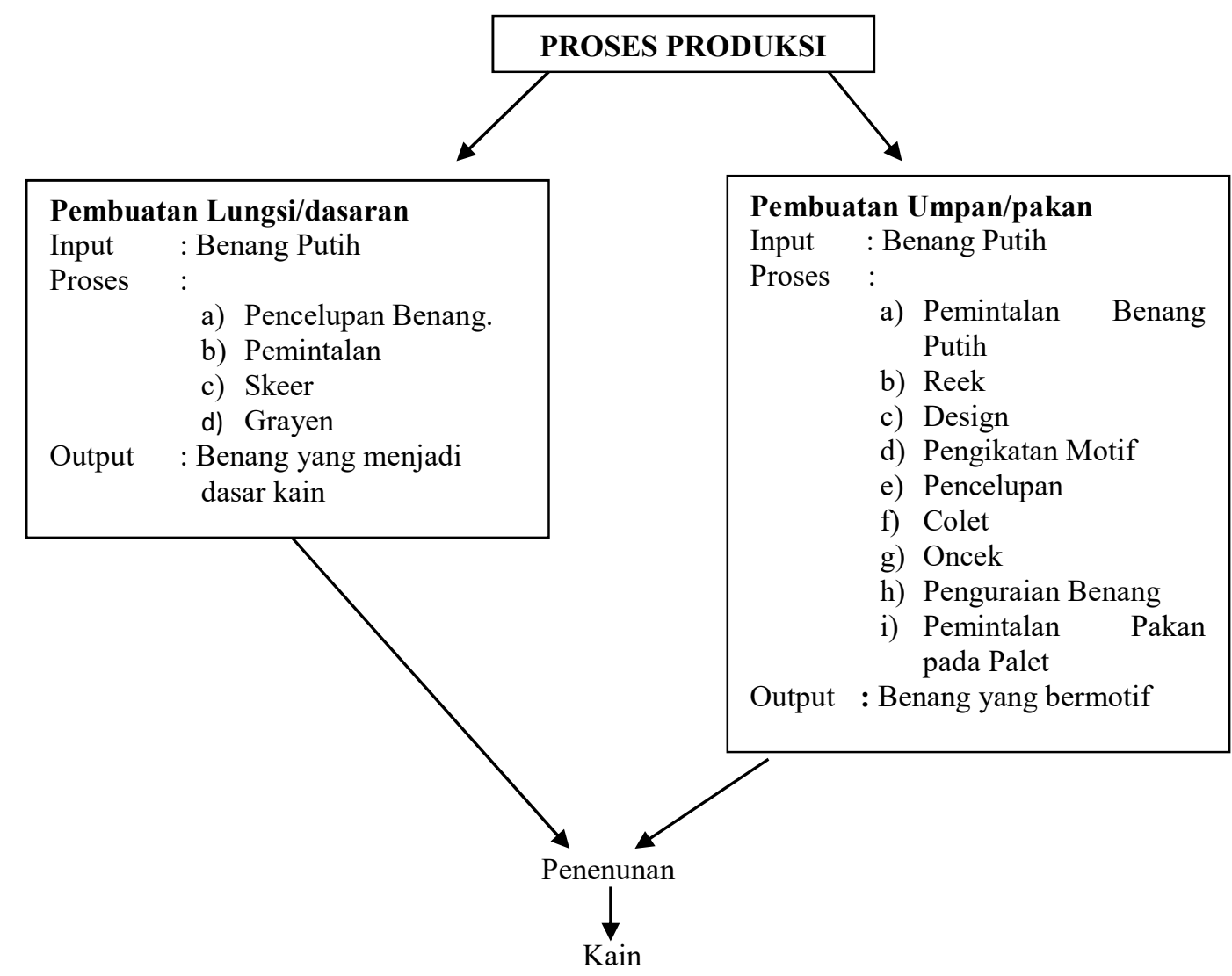

Bagan 1. Proses Produksi Tenun 
Gambar 5. Pelatihan Proses Produksi dan Aneka Kreasi Tenun
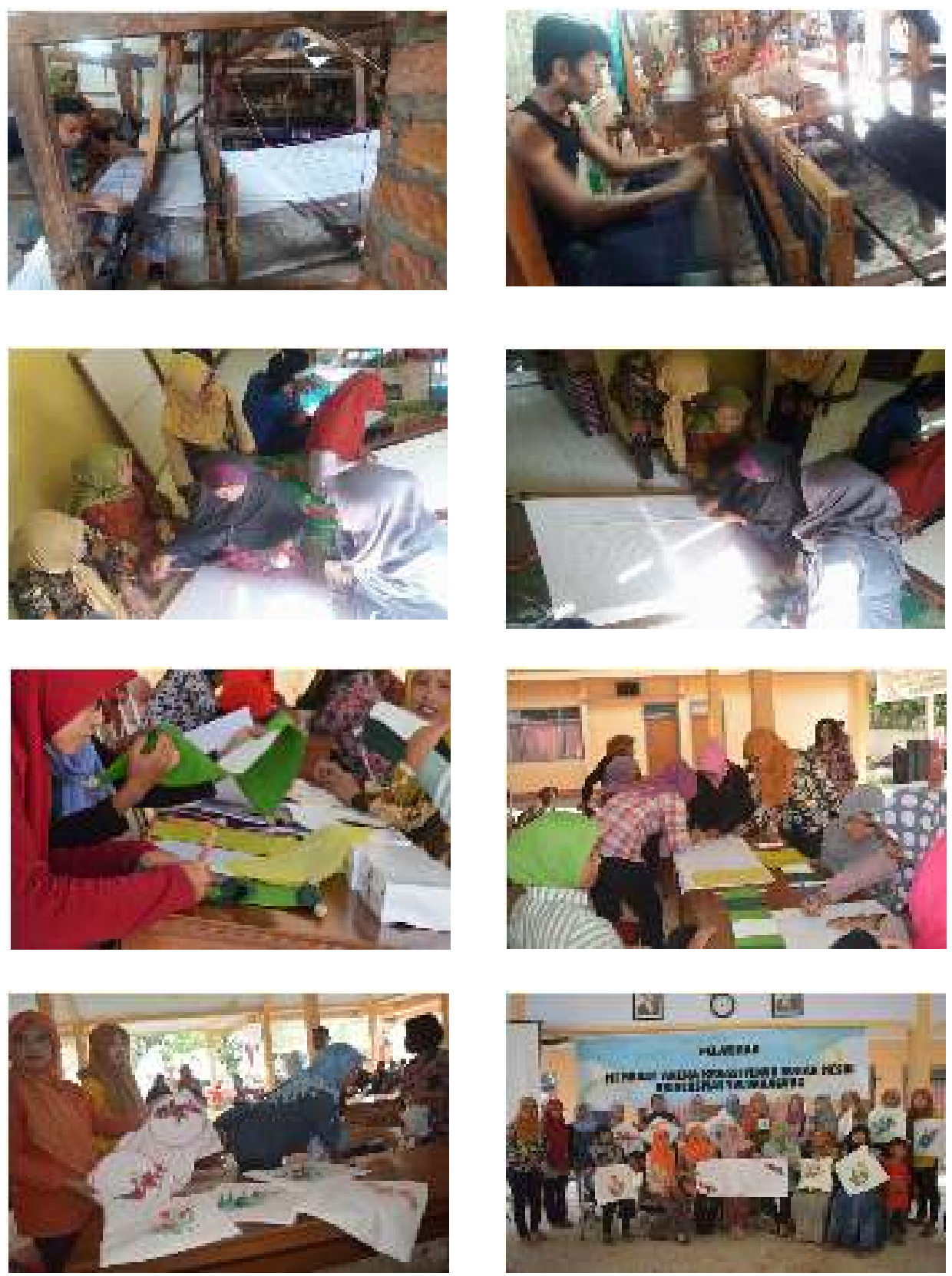

\section{Sarung Bantal}

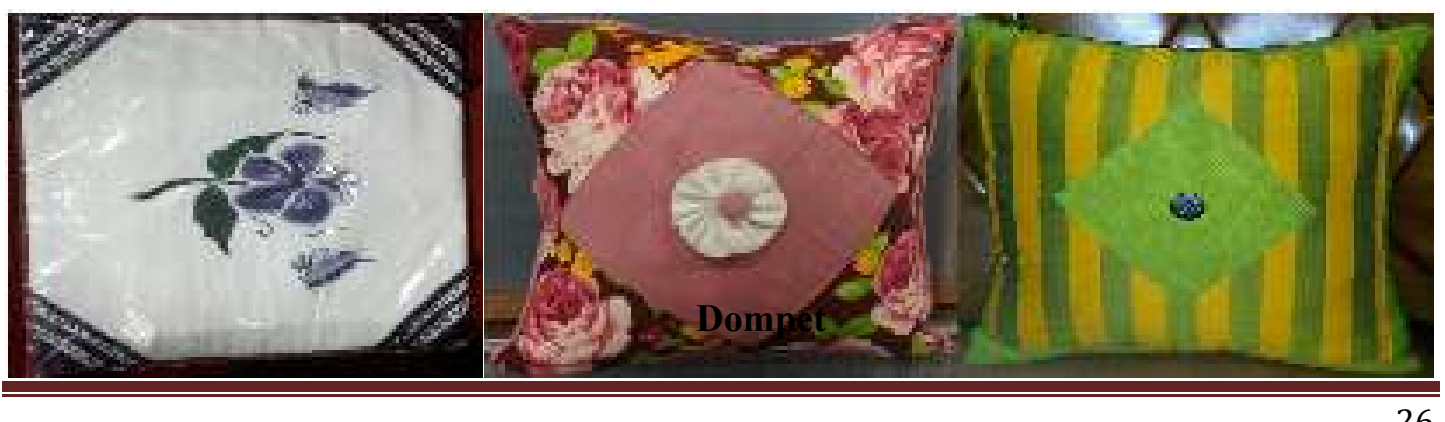

http://ejournal.unita.ac.id/index.php/janita 

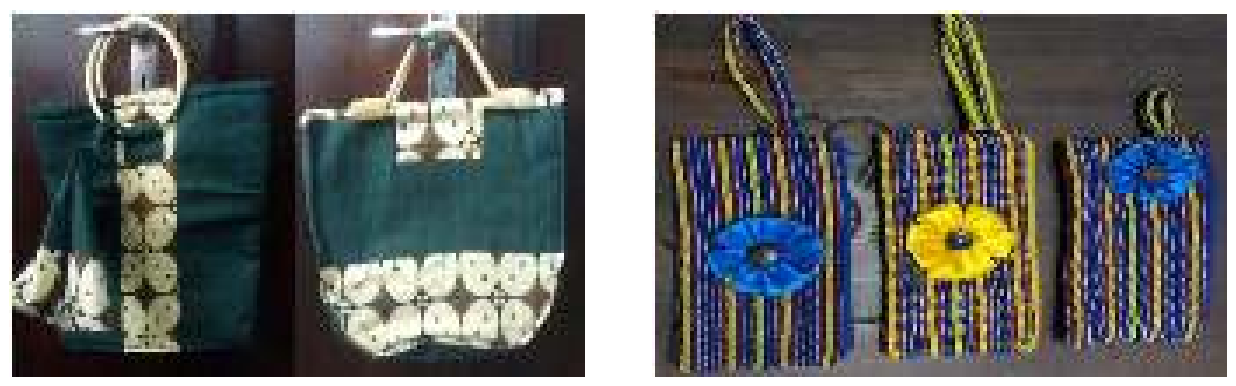

\section{Tempat Tissue}

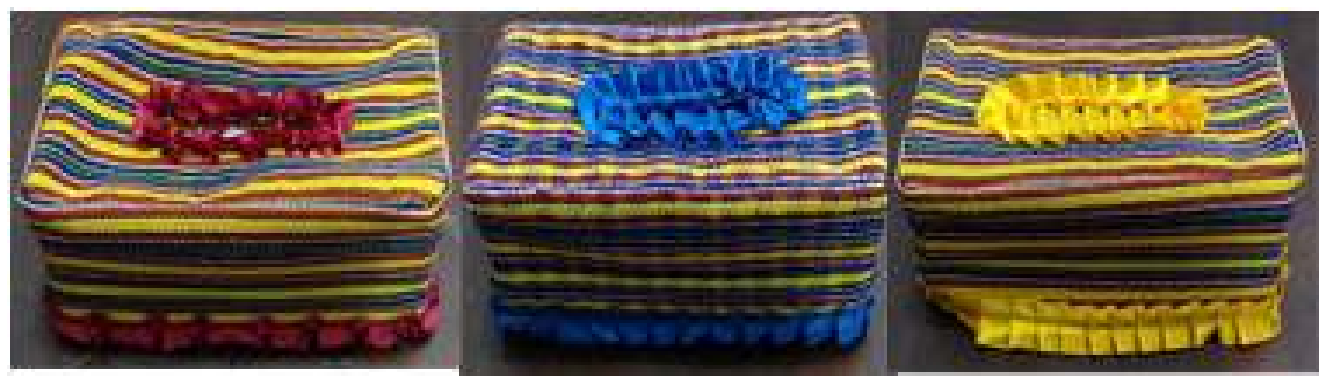

Hiasan Dinding

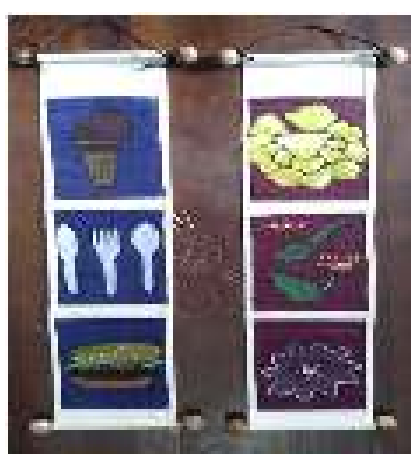

Syal

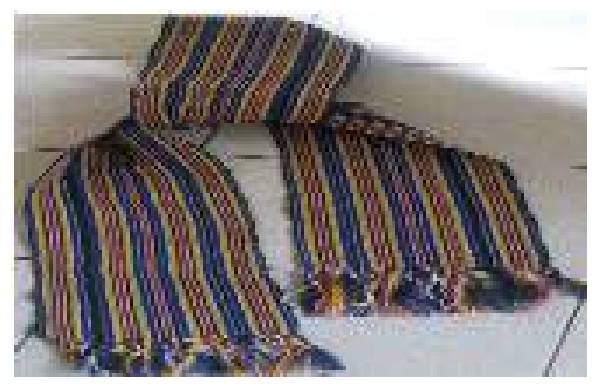

Taplak Meja

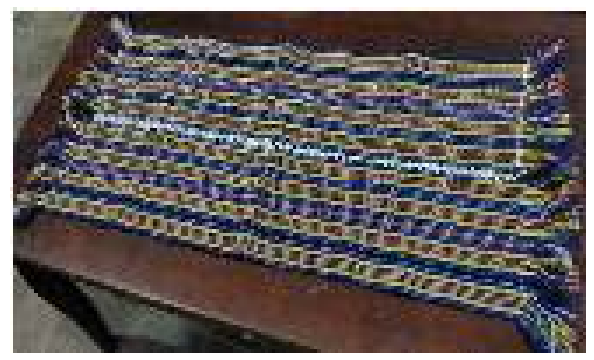




\section{Pelatihan SDM, Manajemen Pemasaran Dan Keuangan}

Tujuan Pelatihan

Metode Pelaksanakan

Peserta

Instructor

Waktu Pelaksanaan

Tempat Pelaksana
: Peningkatan kualitas SDM melalui berbagai kegiatan pelatihan terkait dengan manajemen SDM, Keuangan dan pemasaran

: Tutorial

: Pengrajin tenun bukan mesin di Dusun Talapan Desa Waung, Boyolangu Tulungagung

: 1. Mokhamad Eldon, SE, MM

2. Marlena SE, MM

: 09 Juli 2017

: RW 06, Desa Waung Kecamatan Boyolangu,

Tulungagung

: Web pemasaran produksi

Luaran

Prosedur pelaksanaan kegiatan pelatihan Peningkatan manajemen SDM, Keuangan dan pemasaran

a) Mempersiapkan modul tentang Peningkatan manajemen SDM, Keuangan dan Pemasaran serta menunjukan website yang dibuatkan runtuk memasarkan Produk tenun

b) Menjelaskan manfaat website

c) Mengkopi dan membagikan modul pelatihan sebanyak peserta pelatihan

d) Instruktur menjelaskan Peningkatan manajemen SDM, Keuangan dan

e) Pemasaran dan manfaat website serta bagaimana menggunakannya

f) Tanya jawab dan diskusi

g) Peserta pelatihan mempraktek teori yang diperoleh

Gambar 6. Pelatihan Manajemen Pemasaran (Menggunakan Web) dan Pelaporan Keuangan
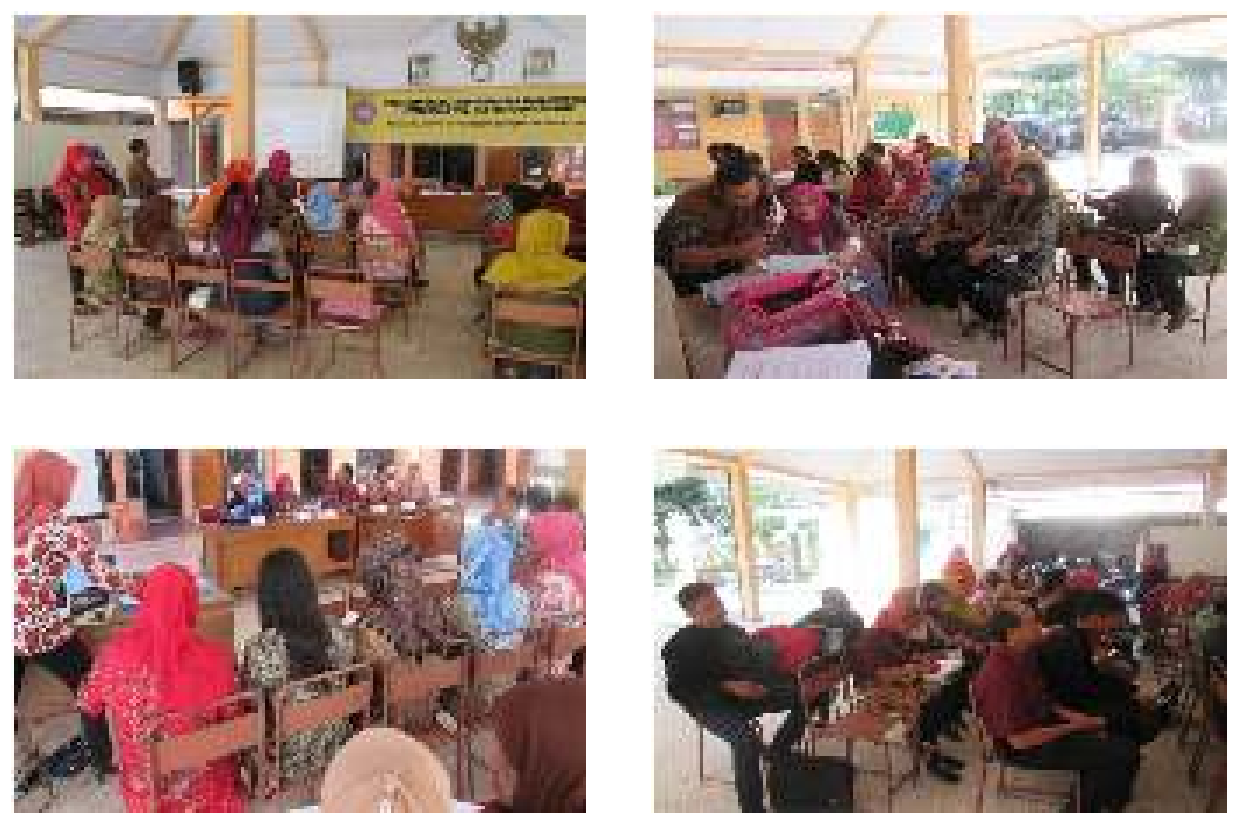


\section{PENUTUP}

\section{Simpulan}

Beberapa hal yang bisa disimpulkan dari kegiatan Pembuatan Tenun Bukan Mesin (TBM) Bermotif untuk Bahan Baku Kerajinan Tangan di Desa Waung Kec.Boyolangu, Kab.Tulungagung dapat dijelaskan antara lain, dari aspek dosen sebagai pelaksana melihat kegiatan pengabdian kepada masyrakat adalah salah satu manisfestasi tugas fungsiona tridarma dosen yang menjadi kewajibannya berkontribusi berpartisipasi dalam akselerasi pembangun masyarakat. Dari sisi manfaat secara institusional, kegiatan pengabdian kepada masyarakat dapat menjadi media untuk bersosialisasi baik bagi individu sebagai tenaga pendidik yang berkewajiban melakukan pengabdian masyarakat maupun institusi dengan masyarakat agar lebih mengenal profile masing-masing. Mengetahui profile lembaga Perguruan Tinggi tempat dimana dosen selaku pelaksana kegiatan pengabdian kepada masyarakat sama pentingnya mengenali profile masyarakat untuk tujuan identifikasi masalah atau kebutuhan yang mungkin bisa dibantu jalan keluarnya.

Rangkaian kegiatan Pembuatan Tenun Bukan Mesin (TBM) Bermotif untuk Bahan Baku Kerajinan Tangan di Desa Waung Kec.Boyolangu, Kab.Tulungagung yang dilakukan bersama-sama dengan 2 kelompok pengrajin tenun sebagai mitra bersama-sama masyarakat sekitar sangat dirasakan manfaatakan. Mereka mendapat pengetahuan bagaimana memperbaiki mutu tenun dan meningkatkan jumlah produksinya. Mereka mendapatkan pelatihan membuat tenun dengan ukuran dan motif yg berbeda dengan tenun yang selama ini mereka produksi yang hanya bisa dimanfatkan sebagai centhing (tali pengikat orang yang memakai kain panjang atau ibu yang baru melahirkan ). Tenun yang diproduksi setelah mengikuti pelatihan memiliki nilai utilitas yang lebih tinggi dan menarik pembeli serta memiliki nilai jual yang lebih karena dapat dimanfaatkan sebagai bahan baku pembuatan bermacammacam item aksesories seperti tempat tisu, tas. dompet, taplak meja, rok dan baju.

Pengetahuan tentang pelatihan penyusunan pelaporan keungan yang diberikan sangat membantu mereka dalam mencatat akuntansi mengolah dan mengumpulkan data finasial, misalnya bukti transksasi untuk pengeluaran kebutuhan pengadaan produksi maupun pendapatan dari penjualan dalam bentuk buku besar dan buku pembantu. Mereka juga memperoleh pengetahuan dan ketrampilan cara-cara menghitung harga pokok produksi dan harga jual dalam rangka menentukan laba usaha.

Kesimpulan lain dari kegiatan pengabdian kepada masyarakat di desa waung adalah mitra dan masyarakat menjadi melek teknologi terutama dalam hal penggunakan web untuk memasarkan produk nya secara effektif, praktis, cepat dan mudah . Penggunakan Web selain dapat membantu expansi area pemasaran yang lebih luas pengenalan produk tenun juga memudahkan transaksi jula beli on line. Konsumen dapat memesan produk yang dikehendaki dan melakukan pembayaran dengan cara mengakses web yang tersedia. 


\section{Saran}

Mengacu pada hasil assessment pelaksanakan kegiatan pengabdian masyarakat yang sudah diuraikan pada bagian kesimpulan yang menunjukan adanya respon positif dari mitra dan mayoritas masyarakat yang mengikuti kegiatan merasa mendapatkan manfaat besar. Terkait dengan tanggapan baik ini, ada beberapa masukan ataupun evaluasi yang mungkin dapat dipergunakan sebagai dasar pertimbangan untuk pelaksanakan kegiatan pengabdian masyarakat menjadi lebih baik lebih tepat sasaran yaitu mengena pada hal-hal yang memang dibutuhkan oleh masyarakat serta memerlukan keterlibatan Perguruan Tinggi dalam pencarian solusi. Dalam perspeptif ini, sikap peduli/ kritis terhadap lingkungan dalam hal ini persoalan social, ekonomi dan budaya setiap anggota civitas akademika (dosen) perlu ditingkatkan. Terkait kontek tenun, pembinaan diharapkan dapat dilaksanakan secara berkesinambungan dan dengan cakupan yang lebih luas sehingga sangat memungkin bisa dikembangkan menjadi desa wisata tenun sebagi wisata edukasi. Keberlanjutan keberadaan tenun mutlak harus dijaga mengingat kemampunan menenun dengan menggunakan alat tenun bukan mesin menjadi warisan budaya masyarakat Indonesia yang bernilai tinggi secara pelan-pellan punah karena hadirnya teknologi modern. Banyak nilai-nilai positif yang bisa dipelajari dari pembuatan tenun bukan mesin. Di antaranya nilai gotong royong, keuletan, kesabaran, kerja keras, tekun dan lain sebagainya. Selain itu minim dengan polusi lingkungan. Harapan selajutnya dosen, Perguruan Tinggi, instansi pemerintah, swasta serta Dikti hendaknya dapat meningkatkan jalinan kerjasamanya bersinergi melakukan kegiatan pengabdian masyarakat dalam rangka mempercepat pembangunan Nasional serta meningkatkan kuota Perguruan Tinggi memperoleh hibah Kegiatan Pengabdian Pada Masyarakat di tahun-tahun mendatang.

\section{E. DAFTAR PUSTAKA}

Ambarwati Maylinda. 2010. Studi Kerajinan Tenun Ikat Sarung Goyor Bapak Sudarto Di Desa Kenteng Kelurahan Pojok Kecamatan Tawangsari. Tersedia dari : URL: https://core.ac.uk/download/files/478/12346018.pdf

BPS. 2015. Tulungagung Dalam Angka (Tulungagung Regency In Figure), Tulungagung, BPS Tulungagung

LPPM Universitas Tulungagung, 2014. Inventarisasi Potensi dan Kekayaan Desa Kabupaten Tulungagung Tahun 2014. LPPM Universitas Tulungagung, Tulungagung. 